\title{
スギ微粉末を用いた酵素糖化反応に及ぼす擋拌速度の影響の検討*
}

\author{
高橋 武彦*1, 佐藤 好希 ${ }^{* 2}$ \\ 伊藤 一志 ${ }^{* 1}$ ，森 英明 ${ }^{* 1}$
}

\section{Effect of Agitation Condition on Enzymatic Hydrolysis of Pulverized Japanese Cedar Powder}

\author{
Takehiko TAKAHASHI ${ }^{* 1}$, Yoshiki SATO, \\ Kazushi ITO and Hideaki MORI
}

${ }^{* 1}$ Akita Prefectural University, 84-4 Tsuchiya-Ebinokuchi, Yurihonjo, Akita, 015-0055 Japan

\begin{abstract}
A vibration mill using cog-ring media, which replaces the ball medium in a conventional vibration mill with a cog-ring medium, was developed to achieve high-impact pulverization of lignocellulosic biomass for producing bio-ethanol. Japanese cedar powder pulverized by the vibration mill using cog-ring media showed that saccharification efficiency in enzymatic saccharification of Japanese cedar powder of greater than $70 \%$ was reached based on holocellulose at tube test. For this study, the effect of agitation speed on enzymatic saccharification was investigated using a pulverized Japanese cedar powder. Results showed that the saccharification efficiency at $10 \%$ solid concentration increased concomitantly with decreasing agitation speed until $30 \mathrm{rpm}$. The best yields of $77 \%$ at $1 \mathrm{~L}$ and $75 \%$ at $3 \mathrm{~L}$ were obtained at $30 \mathrm{rpm}$ agitation. Moreover, relation between Reynolds number for mixing and saccharification efficiency was discussed to find good index for enzymatic saccharification by agitation.
\end{abstract}

Key Words : Pulverization, Lignocellulosic Biomass, Enzymatic Saccharification, Bio-Ethanol

\section{1. 緒言}

近年，植物由来の再生可能な資源を用いてエネルギーを供給することができるバイオマスエネルギーが注目を 浴び，間伐材・製材廃材などの木質系バイオマスからバイオエタノールを製造する技術が研究されている．原料 となる植物は成長する際に二酸化炭素を取り込むため，二酸化炭素を排出しないクリーンなエネルギーとして考 えられる，木質系バイオマスはセルロース，ヘミセルロースおよびリグニンからなる．この中で，セルロース， ヘミセルロースは酵素によりグルコース，マンノースなどの構成単糖に加水分解（酵素糖化）でき，得られた糖 を発酵によりエタノールに変換することが可能となる，一方でリグニンは，酵素糖化に対して阻害因子となる.

したがって，酵素糖化ではリグニンの影響を子予排除して木材中のセルロース，ヘミセルロースを糖変換する必 要がある. 本グループでは，高衝撃力を付加できる歯付リング媒体利用粉砕機 ${ }^{(1)}$ 開発し，60 分の粉砕処理で得 られた平均粒径 $20 \mu \mathrm{m}$ 程度で低結晶化度の杉粉末を酵素糖化し，リグニンの阻害が無いことを明らかにし，70\% を超す酵素糖化率を得ている. また, 粉砕で得られた杉粉末は, 杉粉末濃度 $40 \%$ における酵素糖化から糖濃度 $20 \%$ の糖液を生成 ${ }^{(2)}$, 同時糖化発酵によるエタノール濃度 $6.5 \%$ の生成 ${ }^{(3)}$, 予備糖化を必要とない同時糖化発酵 ${ }^{(4)}$ が可 能など，エタノール製造に有利な特徵を有する.さらには，セルラーゼ酵素によるセルロースの分解が牛の第一 胃であるルーメン内での反応に対応することに着目した，乳牛や肉牛の高エネルギータイプの飼料としての利用 が可能(5)である.このように多様な分野での活用が期待されている.

本研究では，この杉粉末を用いて酵素糖化する場合に，強制的な内部撹拌における擋拌状態が酵素糖化に与え る影響を検討した。 また, 撹拌状態と糖化率の関係を整理するための関係についても考察した.

* 原稿受付 2013 年 8 月 20 日

*1 正員, 秋田県立大学システム科学技術学部（广015-0055 秋田県由利本荘市土谷字海老ノ口 84-4）

*2 秋田県立大学システム科学技術研究科 (現（株) スズキ部品秋田)

E-mail: takehiko_takahashi@akita-pu.ac.jp 


\section{2. 粉砕粉末の調製および粉末の特徴}

本糖化実験に使用する杉粉末は，歯付リング媒体利用粉砕機(6)を用いて粉砾調製した．図 1 に歯付リング媒体 利用粉砕機の外観を示す．粉砕機は，振動式粉砕機をベースとしており，振動ベッドが円運動することで，粉砕 容器内で粉砕が行われる. 図 2 に粉砕容器内に設置する歯付リング媒体の概念図を示す. 粉砕機内部に歯付リン グ媒体が並び，空いている空間に粉砕される杉粗粉末が入る. 60 分の粉砕で得られた杉粉末は，細かくなり繊維 らしき構造は見られず，粒のような状態となる．本研究で用いた杉粉末の性状は，50\%平均粒径が $32.6 \mu \mathrm{m}$, 含 水率が $10.3 \%$, 糖化率が $58.6 \%$ となっている.ここでの糖化率は, 酶酸緩衝液 $2 \mathrm{ml}$ に対して杉粉末濃度 $2 \mathrm{w} / \mathrm{v} \%$, セルラーゼ酵素 $0.1 \mathrm{wt} \%$ で酵素糖化させるビーカ試験 ${ }^{(6)}$ により得られる值で，杉粉末そのものが持つ糖化性を表 す数值であり，糖化率の定義としては次式となる.

$$
\text { 糖化率 }(\%)=\frac{\text { 生成した糖量 }(\mathrm{mg})}{\text { 杉粉末 }(\mathrm{mg}) \times 0.68} \times 100
$$

ここで，0.68 は木材の構成成分中のセルロース，ヘミセルロースの割合の合計でありホロセルロースの割合とな る. また, 酵素による糖化は加水分解反応であるため, このホロセルロースに対する糖化率の最大值は $111 \%$ と なる．以降，本論文では，このホロセルロースに対する糖化率を糖化率と記述する．

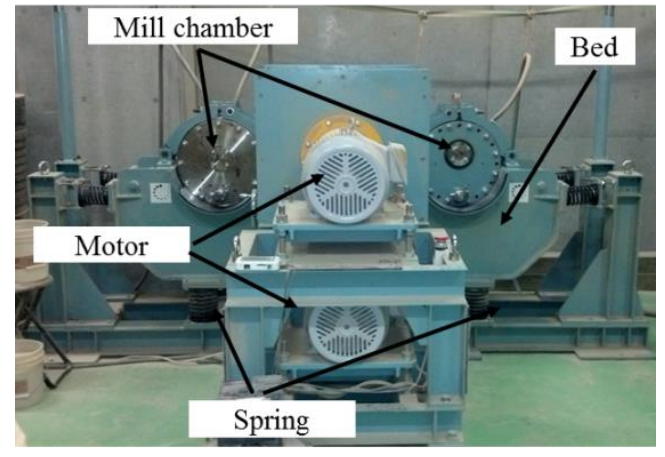

Fig.1 Appearance of the two batch type tandem-ring mill.

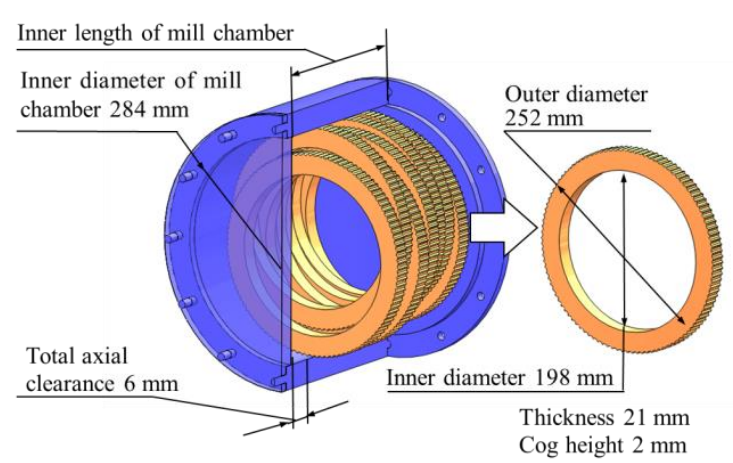

Fig.2 Schema of the cog-grinding mediums installed in the mill chamber of the vibration mill.

\section{3. 擋拌方式酵素糖化試験方法および評価方法}

歯付リング媒体利用粉䂥機を用いて粉砕調製した杉粉末を用いて擋挥および酵素量などの条件を変え，糖化反 応及ぼす擋挥効果を調査した。 図 3 に擋汼方式酵素糖化試験に用いた試験装置の外観と, 装置構成の模式図を示 す. 反応容器には，セパラブルフラスコを用い，擋拌用の羽には綜研テクニックス製 Hi-Fミキサーを用いた. 糖 化試験中の反応容器内の温度は, 反応容器の外側に設けられたウォータージャケットに温水を循環させることで, 一定に保つ仕組みとなっている. 乾式で粉砕調製された杉粉末の特徵の一つとして, 糖化における固形分濃度を 低い值から高い值まで容易に調整できることが挙げられる。この場合, 固形分濃度を高くしたままで, 高い糖化 率を維持できれば, 糖濃度, さらにはエタノール発酵で得られるエタノール濃度を高くすることが可能となり，

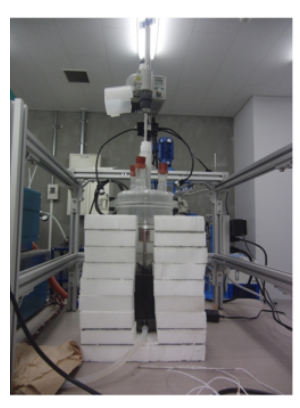

Outline of test equipment

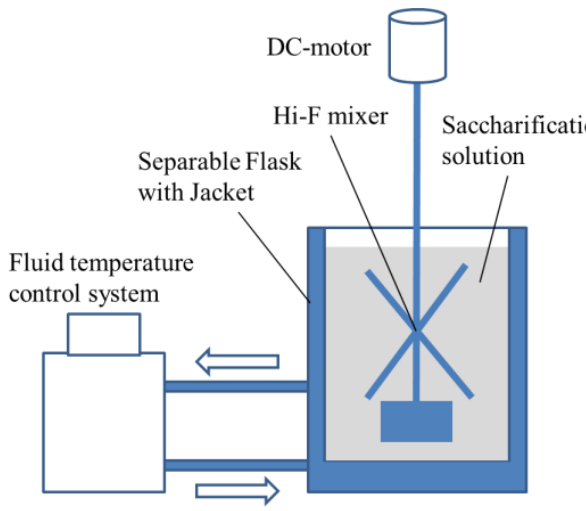

Warm water (50 degrees Celsius)
Table 1 Saccharification test conditions.

\begin{tabular}{|l|l|}
\hline Flask volume & $1 \mathrm{~L}$ and 3L \\
\hline Buffer property & $5.5 \mathrm{pH}, 0.1 \mathrm{M}$ acetic acid buffer \\
\hline Powder concentration & $10 \mathrm{w} / \mathrm{v} \%$ \\
\hline Reaction time & $48 \mathrm{hr}$ \\
\hline Reaction temperature & 50 degrees-Celsius \\
\hline Agitation speed & $0 \sim 100 \mathrm{rpm}$ \\
\hline Enzyme & $\begin{array}{l}\text { Cellulase } \\
\text { (Meicelase, Meij Co., Ltd) }\end{array}$ \\
\hline Enzyme concentration & $0.5,1$ and $5 \mathrm{wt} \%$ for powder \\
\hline
\end{tabular}

Fig.3 Outline of equipment of separable flask and Hi-F mixer, and the saccharification examination system. 
実用面では蒸留におけるエネルギーの低減，糖化，発酵の反応槽の数の削減に寄与できると考える．しかし，杉 粉末濃度を変えた場合，見かけの粘度が大きく変化する，そこで本研究では，どのような流動状態が杉粉末の糖 化反応に寄与できるかを調査するため, 杉粉末濃度を $10 \mathrm{w} / \mathrm{v} \%$ に固定して, 反応容器サイズ, 擋找回転数, およ びセルラーゼ酵素濃度を変えた糖化試験をおこない，その効果について検討した．表 1 に試験条件を示す．試験 では, 一定の擋拌回転数において 48 時間継続しその途中で, 糖化反応液をサンプリングし, その糖化率を評価し た．糖化率の評価は，ビーカ試験における糖化率の評価と同じ方法を用いている.

\section{4. 実験結果および考察}

\section{$4 \cdot 1$ 擋拌方式酵素糖化試験}

図 4 , 図 5 に無擋拌から擋拌回転数 $100 \mathrm{rpm}$ までの擋拌条件において, 糖化試験を行い得られた糖化率の時間 変化を, $1 \mathrm{~L}$ と $3 \mathrm{~L}$ の反応容器サイズ別に示す.いずれの条件においても糖化開始から 12 時間にかけて, 48 時 間後の糖化率の 8 割ほどまで急激に糖化反応が進む. その後, 糖化反応は緩やかとなる. 擋拌回転数で比較する と, $1 \mathrm{~L}$ おび $3 \mathrm{~L}$ のいずれの反応容器においても擋拌回転数 $30 \mathrm{rpm}$ の時の糖化率が高く $77 \%$ と $75 \%$ に達してい

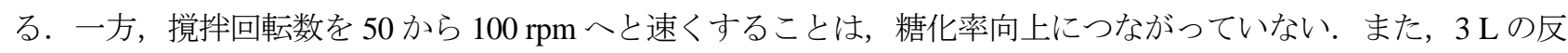
応容器では摚拌回転数を遅くした場合にも差が顕著となる，比較のための実施した無摚拌では，糖化時間のす心゙ てにおいて摚汼を行った場合より低い值となっている.

図 6 に酵素量を変化させた場合の, $1 \mathrm{~L}, 3 \mathrm{~L}$ の反応容器における 48 時間後の最終糖化率と擋拌回転数の関係を 示す. 酵素濃度 $5 \%$ では先に述べたように，擋拌回転数 $30 \mathrm{rpm}$ において糖化率の值が特に高くなっている. 酵素 濃度 $1 \%$ では擋汼回転数 $10 ， 30,50 \mathrm{rpm}$ において糖化実験をおこなっている. しかし，擋汼回転数によらずほぼ 一定の糖化率で推移する結果となった，しかし，酵素濃度 $0.5 \%$ では，再び擋拌回転数 $30 \mathrm{rpm}$ において，糖化率 が高くなる傾向が確認できた. 以上より, 本杉粉末を用いた酵素糖化処理において, Hi-Fミキサーを用いた場合, 擋挥回転数 $30 \mathrm{rpm}$ 付近の回転数において糖化反応を促進する効果があると期待できる.

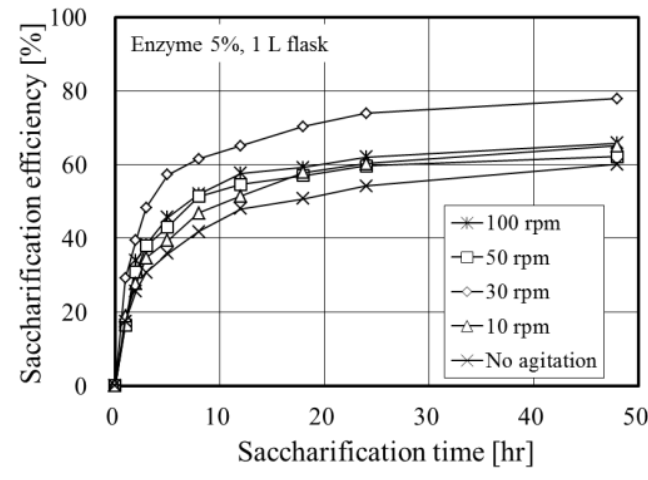

Fig.4 Results of saccharification at conditions of agitation speed and two flask volumes of $1 \mathrm{~L}$ at enzyme $5 \%$.

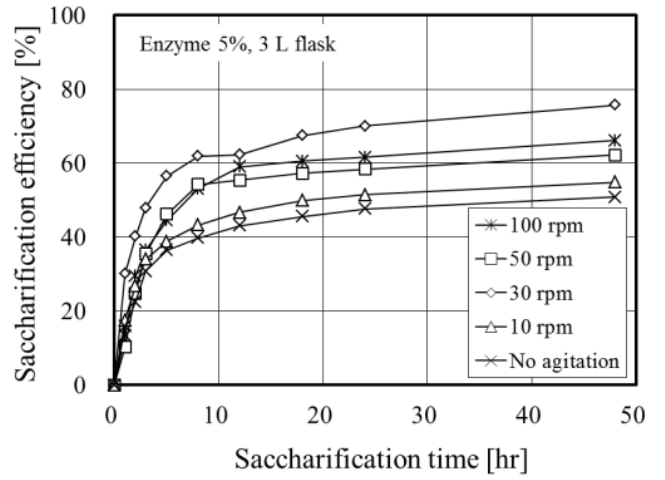

Fig.5 Results of saccharification at conditions of agitation speed and two flask volumes of $3 \mathrm{~L}$ at enzyme $5 \%$.

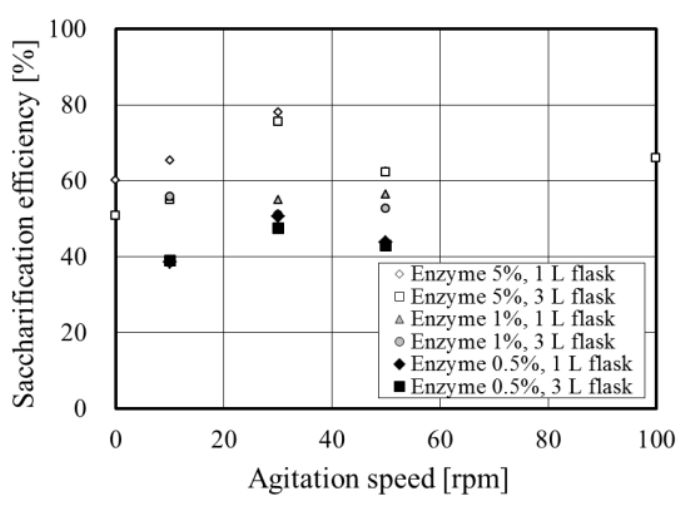

Fig.6 Relation between agitation speed and saccharification efficiency. 


\section{$4 \cdot 2$ 擋拌状態の検討}

糖化における擋拌状態を明らかにするため, 糖化試験中の糖化液の粘度測定を実施した，粘度計は Brook Field 製 LVDV-E を用いた，糖化液は，液体と杉粉末が完全に混合した状態で粘度計にセットしても，時間経過ととも に杉粉末の沈殿が進行する.そのため, 測定開始後 20 秒の時点での粘度をその代表粘度として記録した.この際， 糖化時の温度を保つため糖化実験装置と同様に保温ジャケットを用いて温度一定の条件下で, 粘度測定を実施し た. 図 7 に杉粉末濃度 $10 \%$ ，酵素量 $5 \%$ ，摚拌回転数 $50 \mathrm{rpm}$ における糖化率と糖化液の粘度の関係を示す. 粘度 の全体的な変化としては，糖化開始後の 3 時間までに急激に上昇し， 5 時間の時点でピークとなる $2.0 \mathrm{mPa}$ に達 し，その後は試験終了となる 48 時間まで緩やかに低下寸る傾向が確認できる.この初期の粘度の増加に対応する ように，糖化率も急激に増加し，粘度の変化が少なくなると糖化率も変化が小さくなっている．したがって，糖 化率の急激な上昇と粘度の急激な上昇には関連性があると考えられる．糖化率の上昇で増加するのは，糖液中の 糖量であり，杉粉末を含まない糖液として糖濃度 $0 ， 30 ， 60,90 ， 120 ， 150 \mathrm{mg} / \mathrm{mL}$ の標準液を作成し粘度を測 定した. その結果, 粘度は $1.16 \sim 1.36 \mathrm{mPa} \cdot \mathrm{s}$ とほとんじ変化しない結果となった. したがって, この糖化反応に おける粘度の増加は，糖濃度の影響ではなく，別の要素によるものと考えられる.

次に，糖化における杉粉末の粒径の変化と粘度の関係ついて検討する．図 8 に杉粉末濃度 $10 \%$, 酵素量 5\%, 摚拌回転数 $50 \mathrm{rpm}$ での糖化試験における杉粉末の平均粒径と粘度の変化の関係を示す．実験開始時に平均粒径 $32.6 \mu \mathrm{m}$ であったものが，糖化試験開始後 1 時間の時点で, $12 \mu \mathrm{m}$ にまで大幅に小粒径化し，その後 8 時間までに 粒径 $25 \mu \mathrm{m}$ 程度に大きくなる．以降は，糖化終了まであまり変化せずに推移している．これには，糖化反応によ る杉粉末の粒子表面の形状変化と杉粉末同士の凝集が関係していると考えられる. 粘度は糖化開始 5 時間までに 急激に上昇し，その後なだらかな減少傾向となる．したがって，糖化開始と共に酵素が杉粉末を糖に分解するこ とで杉粉末の粒径が小さくなり，この粒径の変化が糖化液の粘度に影響を与えているものと考える.

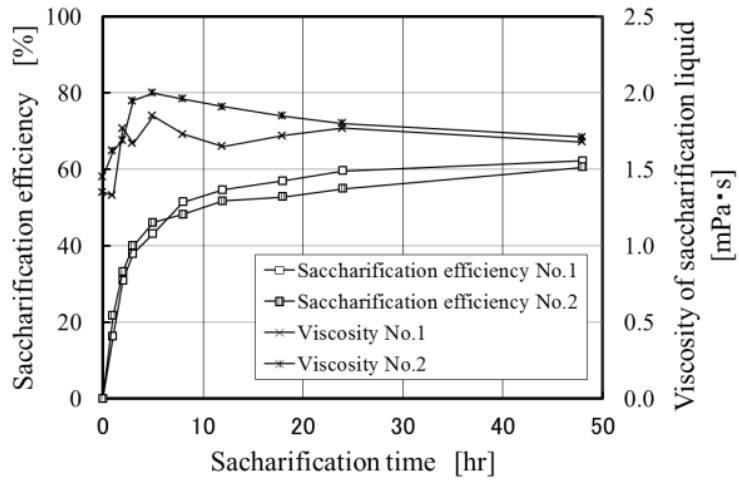

Fig.7 Relation between the saccharification efficiency and viscosity of saccharification liquid.

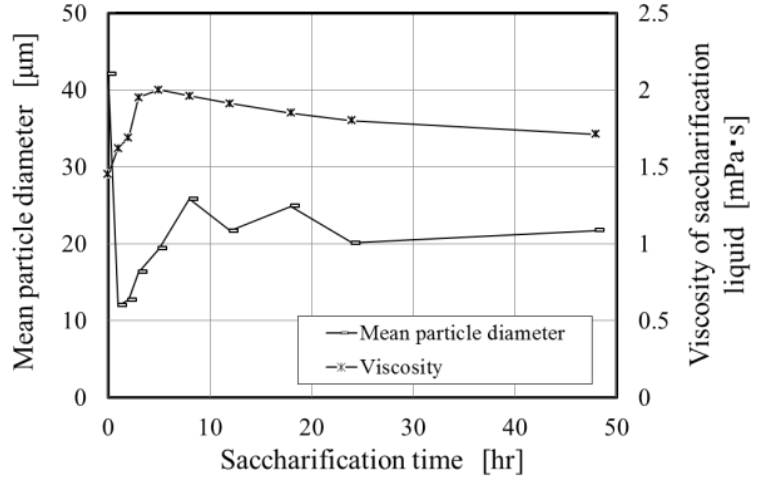

Fig.8 Relation between the mean particle diameter and viscosity of saccharification liquid.

次に測定した粘度の值を元に，擋拌レイノルズ数を求め摚拌状態を評価した．擋拌レイノルズ数 Re は次式で 定義される.

$$
\operatorname{Re}=\frac{D^{2} N \rho}{\mu}
$$

ここで, $D:$ 翼直径 $[\mathrm{m}] \quad N$ : 回転数 $[\mathrm{rpm}] \rho:$ 密度 $\left[\mathrm{kg} / \mathrm{m}^{3}\right] \mu:$ 粘度 $[\mathrm{Pa} \mathrm{s}]$ である.

図 9 にそれぞれの擋拌翼サイズにおける擋找レイノルズ数と糖化率の関係を示寸.評価に使用した粘度の值は, 48 時間時点の粘度とした. $1 \mathrm{~L}$ の反応容器の擋挥翼の場合, 擋拌回転数 $30 \mathrm{rpm}$ では擋拌レイノルズ数は $\mathrm{Re}=1152$ と層流域にあると言える. しかし， $3 \mathrm{~L}$ の反応容器の摚拌翼の場合 $30 \mathrm{rpm}$ においては $\mathrm{Re}=2549$ となりこの值は 遷移域にあたる．以上のことから，擋找レイノルズ数は翼直径に応じて Re 值が変化する．また，擋找レイノル ズ数には糖化時間の要素が入っていない，そこで，擋拌レイノルズ数 Re と糖化時間を乗じて擋拌の時間的な蓄 積という考え方を導入し, さらに実験の容器サイズも考慮に入れるため, 容器の体積で割ることで, 単位体積当

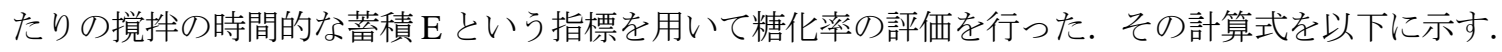




$$
E \propto \operatorname{Re} \cdot \frac{t}{V}
$$

ここで, Re : 撹拌レイノルズ数 $t$ : 糖化時間 $[\mathrm{s}] \quad V$ : 糖化フラスコ容量 $\left[\mathrm{m}^{3}\right]$ オある.

図 10 に，単位体積当たりの撹挥入力時間と糖化率の関係を示す. 各種パラメータが盛り込まれた Re・ $t / V に$ 対する糖化率の值の分布が，1本の線上に乗っているように捉える事ができている.これにより，撹䢁回転数， 反応容器サイズ，糖化時間を含めた評価式において，糖化率が上昇している関係を明らかにできる。これより， 各糖化パラメータを組み込み，糖化率との関係を表すことで，糖化率の指標にできると考える.

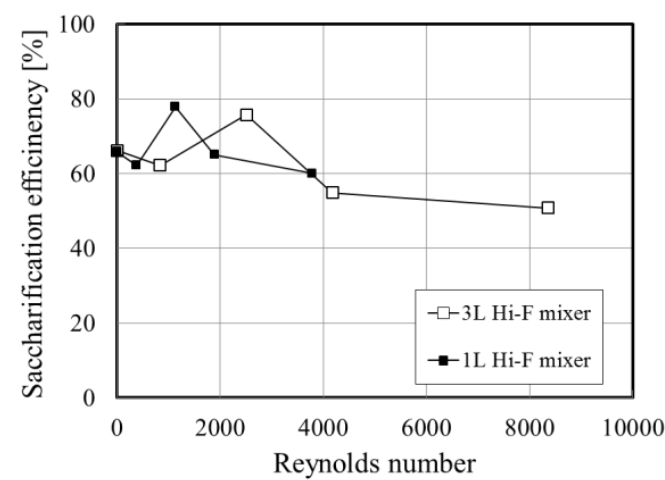

Fig.9 Relation between Reynolds number for mixing and saccharification efficiency at enzymatic saccharification.

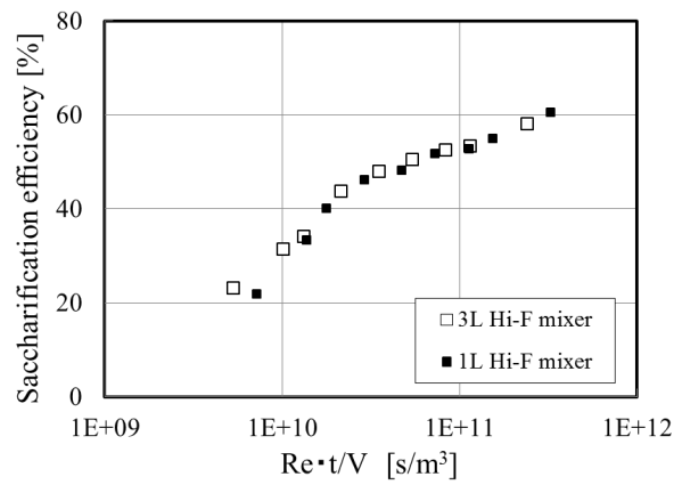

Fig.10 Relation between the mixing energy per unit volume and saccharification efficiency at enzymatic saccharification.

\section{5. 結}

本研究では杉粉末を用いた酵素糖化法において，杉粉末の酵素糖化における撹拌の指標となる関係性を表すこ とを目的とし，糖化率と粒径変化，粘度の関係を調査した。 その結果，得られた知見を以下に示す.

(1) 撹汼回転数 $30 \mathrm{rpm}$ で高糖化率が得られる.

(2) 糖化における粘度の変化は, 糖化時の粒径の変化と密接に関係している.

（3）撹拌状態を表す代表的な指標である擋拌レイノルズ数に対して，単位体積当たりの擋拌の時間的な蓄積を 導入することで，酵素糖化反応の撹拌状態を踏まえた糖化率の指標とすることができる.

今後は，杉粉末濃度を高くし，容器サイズを大型化し，データ蓄積を行い，さらなる検討を進める予定である.

\section{謝 辞}

本研究の一部は，平成 24 年度の NEDO の助成事業「新エネルギーベンチャー技術革新事業（フェーズ C）」 の成果である.ここに記して，謝意を表する.

\section{文献}

(1) 高橋武彦, 伊藤新, 遠田幸生, 伊藤一志，小林淳一，“木質系バイオマス微粉砕のための歯車型粉砕媒体利用粉砕 機の研究開発”，日本機械学会論文集 B 編，Vol. 76，No. 770 (2010)，pp. 1654-1660.

(2) 遠田幸生, 小林淳一, 高橋武彦, 伊藤一志, 伊藤新, “インナーパワーリング粉砕機を利用した杉粉末の高濃度糖 液への変換技術に関する研究”，第 4 回バイオマス科学会議 発表論文集 (2009), pp. 104-105.

（3）遠田幸生，竹村卓也，沓名潤子，佐藤和美 他，“タンデムリングミル粉砕物の同時糖化発酵によるバイオエタノー ルの高濃度化”，第 7 回バイオマス科学会議＼cjkstart発表論文集 (2012), pp. 16-17.

(4) 梅澤俊策, 高橋武彦, 伊藤一志, 小林淳一, 伊藤新, 進藤昌, “乾式微粉砕した杉材の酵素糖変換・エタノール变 換の研究” 日本機械学会論文集 B 編，Vol. 78，No. 787 (2012)，pp. 405-409.

（5）上松仁，高橋武彦，渡邊潤，“木を食料にする 一木の微粉砕によるセルロース系濃厚飼料の開発一”，木材情報， No. 257 (2012), pp. 11-16.

(6) 高橋武彦, 伊藤新, 遠田幸生, 伊藤一志, 小林淳一, “木質系バイオマス微粉砕効率向上のための歯車型リング媒 体利用粉砕機の研究開発” 日本機械学会論文集 B 編，Vol. 78，No. 788 (2012)，pp. 905-916. 